\title{
Effect of Various Choline Esters upon the Secretion Rate of Adrenaline and Noradrenaline of the Adrenal Gland
}

\author{
By \\ Masayoshi Kamo \\ Department of Physiology, Nagasaki University School of \\ Medicine, Nagasaki
}

(Received for publication, November 11, 1961)

It is well established that the administration of acetylcholine induces an increase in the secretion rate of the adrenal medullary hormone. It was also reported that other choline esters, such as carbaminoylcholine ${ }^{1 /-6)}$ and benzoylcholine, ${ }^{61,7)}$ caused an augmentation of the adrenal medullary secretion.

In most mammals noradrenaline is liberated from the adrenal gland along with adrenaline. Recently, a number of investigators estimated the relative proportion of adrenaline and noradrenaline liberated from the adrenal gland into the adrenal vein blood. In their studies the secretion rates of adrenaline and noradrenaline were mostly calculated from the catecholamine contents of the adrenal venous plasma and the blood flow of the adrenal gland. However, as was pointed out by Weil-Malherbe and Bone, ${ }^{8}$ the proportion of adrenaline and noradrenaline in plasma is not always the same as that in the blood cells. Thus, for estimating exactly the adrenaline and noradrenaline secretion rate of the adrenal gland, it is desirable to use whole blood rather than plasma of adrenal venous blood.

In the present study the effects of acetylcholine, carbaminoylcholine and benzoylcholine upon the adrenal medullary secretion rate were evaluated by estimating adrenaline and noradrenaline contents of the adrenal venous blood.

\section{METHODS}

Eleven dogs, weighing 6-12 kg, were used in experiments. The animals were anesthetized with sodium pentobarbital (Nembutal, Abbstt) and the samples of adrenal venous blood were collected by the lumbar route method of Satake, Sugawara and Watanabe.9) In order to register the blood pressure, the femoral artery was connected with a mercury manometer. For injection of chemicals the saphenous vein was prepared and a small glass cannula was inserted into the vein.

Acetylcholine chloride (Hoffmann-La Roche), carbaminoylcholine chloride 
(Doryl, Merck) and benzoylcholine chloride (Hoffmann-La Roche) were injected intravenously in doses of $1-2,0.25-0.5$, and $2-4 \mathrm{mg} / \mathrm{kg}$ of body weight, respectively.

Generally, two adrenal venous blood samples for estimating the control secretion rate were collected. Then, an intravenous injection of one of the choline esters was made in 15 seconds. Simultaneously with the initiation of injection, adrenal venous blood collection was started and 30 -second period blood collections were performed successively three times.

One cc of the adrenal venous blood sample was added to a solution containing $2 \%$ sodium fluoride and $3 \%$ sodium thiosulphate. Then, $0.5 \mathrm{cc}$ of $5 \%$ cetrimide solution was added. After completion of hemolysis, deproteinization was made by adding $8 \mathrm{cc}$ of $1 / 12 \mathrm{~N}$ sulfuric acid and $1 \mathrm{cc}$ of $10 \%$ sodium tungstate. Then, a differential estimation of adrenaline and noradrenaline was performed by the method of Weil-Malherbe and Bone. ${ }^{81}$

\section{RESULTS}

The secretion rate of adrenaline and noradrenaline increased in all cases after injection of choline esters, the maximum secretion rate being observed in the first 30-second period after the start of injection. In the second 30 -second period it decreased and resumed the pre-injection secretion rate or somewhat higher than the latter. The secretion rates of the first 30 -second period after acetylcholine injection as well as the pre-injection control secretion rates are shown in Table I. In Tables II and III are listed the secretion rates before and after injection of carbaminoylcholine and benzoylcholine, respectively.

Effect of acetylcholine on the adrenaline and noradrenaline secretion rates of the adrenal gland

Acetylcholine in doses of 1 and $2 \mathrm{mg} / \mathrm{kg}$ was injected in four dogs.

Before injection of $1 \mathrm{mg} / \mathrm{kg}$ acetylcholine, the secretion rate of the total catecholamines, i.e., adrenaline plus noradrenaline, was $0.020 \mu \mathrm{g} / \mathrm{kg} / \mathrm{min}$. $(0.014-$ 0.027 ) in $\operatorname{dogs} 1,2$, and 4 . The relative content of noradrenaline of the adrenal venous blood was calculated as $31 \%(10-67)$ of total catecholamines. In $\operatorname{dog} 3$ the amount of noradrenaline in adrenal venous blood samples was unmeasurably small, i.e., less than $0.01 \mu \mathrm{g} / \mathrm{cc}$. After injection of $1 \mathrm{mg} / \mathrm{kg}$ acetylcholine, the adrenaline and noradrenaline secretion rates increased to $0.50 \mu \mathrm{g} / \mathrm{kg} / \mathrm{min}$. $(0.27-$ 0.76 ) and $0.15 \mu \mathrm{g} / \mathrm{kg} / \mathrm{min}$. $(0.040-0.46)$, respectively. The relative noradrenaline content was $18 \%(9-37)$.

Before injection of $2 \mathrm{mg} / \mathrm{kg}$ acetylcholine the secretion rate of total catecholamines was $0.019 \mu \mathrm{g} / \mathrm{kg} / \mathrm{min} .(0.004-0.037)$ in $\operatorname{dogs~2,3,~and~4.~And~the~}$ relative noradrenaline content was $32 \%(10-67)$ of the total catecholamines. In $\operatorname{dog} 1$, however, the noradrenaline content of the adrenal venous blood was unmeasurably small. 
TABLE I. Effect of Acetylcholine upon the Secretion Rate of Adrenaline and Noradrenaline of the Adrenal Gland in the Dog

\begin{tabular}{|c|c|c|c|c|c|c|c|}
\hline \multirow{4}{*}{$\begin{array}{l}\text { Animal } \\
\text { No. }\end{array}$} & \multirow{4}{*}{$\begin{array}{l}\text { Body wt. } \\
\quad(\mathrm{kg}) \\
\text { and sex }\end{array}$} & \multirow{4}{*}{$\begin{array}{l}\text { Dose of } \\
\text { acetyl- } \\
\text { choline } \\
(\mathrm{mg} / \mathrm{kg})\end{array}$} & \multicolumn{3}{|c|}{$\begin{array}{l}\text { Adrenaline and noradrenaline } \\
\text { in adrenal venous blood }\end{array}$} & \multirow{2}{*}{\multicolumn{2}{|c|}{$\begin{array}{c}\text { Secretion rate of } \\
\text { adrenaline and noradrenaline } \\
(\mu \mathrm{g} / \mathrm{kg} / \mathrm{min} .)\end{array}$}} \\
\hline & & & \multirow{2}{*}{\multicolumn{2}{|c|}{$\begin{array}{c}\text { Concentration } \\
(\mu \mathrm{g} / \mathrm{cc})\end{array}$}} & \multirow{3}{*}{$\begin{array}{l}\text { Per cent } \\
\text { noradre- } \\
\text { naline }\end{array}$} & & \\
\hline & & & & & & Adr. & Noradr. \\
\hline & & & Adr. & Noradr. & & & \\
\hline 1 & $\begin{array}{l}8.6 \\
q\end{array}$ & $\begin{array}{l}1.0 \\
2.0\end{array}$ & $\begin{array}{c}(0.04) \\
(0.03) \\
1.27 \\
(0.01) \\
(0.02) \\
2.38\end{array}$ & $\begin{array}{c}(0.01) \\
(0.01) \\
0.76 \\
(*) \\
(*) \\
0.27\end{array}$ & $\begin{array}{c}(20) \\
(25) \\
37\end{array}$ & $\begin{array}{c}(0.016) \\
(0.013) \\
0.76 \\
(0.005) \\
(0.009) \\
1.60\end{array}$ & $\begin{array}{c}(0.004) \\
(0.004) \\
0.46 \\
0.18\end{array}$ \\
\hline 2 & $\begin{array}{l}9.2 \\
f\end{array}$ & 2.0 & $\begin{array}{c}(0.03) \\
(0.03) \\
0.55 \\
(0.02) \\
(0.02) \\
1.70\end{array}$ & $\begin{array}{c}(0.06) \\
(0.03) \\
0.07 \\
(0.04) \\
(0.01) \\
0.18\end{array}$ & $\begin{array}{c}(67) \\
(50) \\
11 \\
(67) \\
(33) \\
10\end{array}$ & $\begin{array}{c}(0.006) \\
(0.007) \\
0.31 \\
(0.006) \\
(0.006) \\
0.82\end{array}$ & $\begin{array}{c}(0.013) \\
(0.007) \\
0.040 \\
(0.011) \\
(0.003) \\
0.090\end{array}$ \\
\hline 3 & 12.0 & $\begin{array}{l}1.0 \\
2.0\end{array}$ & $\begin{array}{c}(0.03) \\
(0.03) \\
0.96 \\
(0.02) \\
(0.05) \\
1.92\end{array}$ & $\begin{array}{c}(*) \\
(*) \\
0.18 \\
(0.01) \\
(0.03) \\
0.17\end{array}$ & $\begin{array}{c}16 \\
(33) \\
(38) \\
9\end{array}$ & $\begin{array}{c}(0.005) \\
(0.004) \\
0.27 \\
(0.003) \\
(0.011) \\
0.61\end{array}$ & $\begin{array}{c}0.050 \\
(0.001) \\
(0.006) \\
0.054\end{array}$ \\
\hline 4 & $\begin{array}{l}8.8 \\
\vdots\end{array}$ & 2.0 & $\begin{array}{c}(0.09) \\
(0.07) \\
1.86 \\
(0.10) \\
(0.10) \\
3.71\end{array}$ & $\begin{array}{c}(0.01) \\
(0.01) \\
0.18 \\
(0.01) \\
(0.01) \\
0.25\end{array}$ & $\begin{array}{c}(10) \\
(13) \\
9 \\
(10) \\
(10) \\
6\end{array}$ & $\begin{array}{c}(0.022) \\
(0.024) \\
0.67 \\
(0.025) \\
(0.034) \\
1.78\end{array}$ & $\begin{array}{c}(0.002) \\
(0.003) \\
0.065 \\
(0.003) \\
(0.003) \\
0.12\end{array}$ \\
\hline
\end{tabular}

The values in parentheses represent the pre-injection ones.

* Immeasurably small amount of noradrenaline.

After injection of $2 \mathrm{mg} / \mathrm{kg}$ acetylcholine the secretion rate of adrenaline increased to $1.20 \mu \mathrm{g} / \mathrm{kg} / \mathrm{min}$. (0.61-1.78) and that of noradrenaline to $0.11 \mu \mathrm{g} / \mathrm{kg} /$ min. (0.054-0.18). The relative noradrenaline content was 9\% (6-10).

Effect of carbaminoylcholine on the adrenaline and noradrenaline secretion rates of the adrenal gland

Injections of carbaminoylcholine in doses of 0.25 and $0.5 \mathrm{mg} / \mathrm{kg}$ were done in three dogs.

Before injection of $0.25 \mathrm{mg} / \mathrm{kg}$ carbaminoylcholine the total catecholamine secretion rate of the adrenal gland was $0.028 \mu \mathrm{g} / \mathrm{kg} / \mathrm{min} .(0.018-0.040)$ with the noradrenaline percentage of $32 \%(17-43)$. After injection the maximum adrenaline secretion rate was found to be $0.52 \mu \mathrm{g} / \mathrm{kg} / \mathrm{min} .(0.32-0.71)$ and that of 
TABLE II. Effect of Carbaminoylcholine upon the Secretion Rate of Adrenaline and Noradrenaline of the Adrenal Gland in the Dog

\begin{tabular}{|c|c|c|c|c|c|c|c|}
\hline \multirow{4}{*}{$\begin{array}{l}\text { Animal } \\
\text { No. }\end{array}$} & \multirow{4}{*}{$\begin{array}{l}\text { Body wt. } \\
(\mathbf{k g}) \\
\text { and sex }\end{array}$} & \multirow{4}{*}{$\begin{array}{c}\text { Dose of } \\
\text { carbami- } \\
\text { noylcholine } \\
(\mathrm{mg} / \mathrm{kg})\end{array}$} & \multicolumn{3}{|c|}{$\begin{array}{l}\text { Adrenaline and noradrenaline } \\
\text { in adrenal venous blood }\end{array}$} & \multirow{2}{*}{\multicolumn{2}{|c|}{$\begin{array}{l}\text { Secretion rate of adrenaline } \\
\text { and noradrenaline } \\
(\mu \mathrm{g} / \mathrm{kg} / \mathrm{min} .)\end{array}$}} \\
\hline & & & \multirow{2}{*}{\multicolumn{2}{|c|}{$\begin{array}{l}\text { Concentration } \\
(\mu \mathrm{g} / \mathrm{cc})\end{array}$}} & \multirow{3}{*}{$\begin{array}{l}\text { Per cent } \\
\text { noradre- } \\
\text { naline }\end{array}$} & & \\
\hline & & & & & & Adr. & Noradr. \\
\hline & & & Adr. & Noradr. & & & \\
\hline 5 & $\begin{array}{l}7.1 \\
0\end{array}$ & $\begin{array}{l}0.25 \\
0.50\end{array}$ & $\begin{array}{c}(0.05) \\
(0.05) \\
1.24 \\
(0.06) \\
(0.05) \\
3.04 \\
\end{array}$ & $\begin{array}{c}(0.02) \\
(0.02) \\
0.33 \\
(0.01) \\
(0.01) \\
0.96\end{array}$ & $\begin{array}{c}(29) \\
(29) \\
21 \\
(14) \\
(17) \\
24 \\
\end{array}$ & $\begin{array}{l}(0.019) \\
(0.021) \\
0.52 \\
(0.017) \\
(0.014) \\
1.22 \\
\end{array}$ & $\begin{array}{c}(0.007) \\
(0.008) \\
0.14 \\
(0.003) \\
(0.003) \\
0.38\end{array}$ \\
\hline 6 & $\begin{array}{l}6.9 \\
9\end{array}$ & 0.50 & $\begin{array}{c}(0.04) \\
(0.05) \\
0.59 \\
(0.05) \\
(0.05) \\
1.49\end{array}$ & $\begin{array}{c}(0.02) \\
(0.01) \\
0.37 \\
(0.01) \\
(0.01) \\
0.73\end{array}$ & $\begin{array}{c}(33) \\
(17) \\
39 \\
(17) \\
(17) \\
33\end{array}$ & $\begin{array}{c}(0.012) \\
(0.017) \\
0.32 \\
(0.011) \\
(0.014) \\
0.64 \\
\end{array}$ & $\begin{array}{c}(0.006) \\
(0.003) \\
0.20 \\
(0.002) \\
(0.003) \\
0.31\end{array}$ \\
\hline 7 & $\begin{array}{c}6.6 \\
\vdots\end{array}$ & 0.50 & $\begin{array}{c}(0.04) \\
(0.06) \\
2.62 \\
(0.02) \\
(0.02) \\
2.53\end{array}$ & $\begin{array}{c}(0.03) \\
(0.04) \\
1.51 \\
(0.01) \\
(0.02) \\
1.26\end{array}$ & $\begin{array}{c}(43) \\
(40) \\
37 \\
(33) \\
(50) \\
33\end{array}$ & $\begin{array}{c}(0.023) \\
(0.019) \\
0.71 \\
(0.007) \\
(0.007) \\
1.46\end{array}$ & $\begin{array}{c}(0.017) \\
(0.013) \\
0.41 \\
(0.004) \\
(0.007) \\
0.73\end{array}$ \\
\hline
\end{tabular}

The values in parentheses represent the pre-injection ones.

noradrenaline was $0.25 \mu \mathrm{g} / \mathrm{kg} / \mathrm{min}$. $(0.14-0.41)$. The noradrenaline percentage was $32 \%(21-39)$ of the total catecholamines.

Before injection of $0.5 \mathrm{mg} / \mathrm{kg}$ carbaminoylcholine, the secretion rate of the total catecholamines was $0.015 \mu \mathrm{g} / \mathrm{kg} / \mathrm{min}$. (0.011-0.020) and the relative noradrenaline concentration was $25 \%(14-50)$. After injection of $0.5 \mathrm{mg} / \mathrm{kg}$ carbaminoylcholine the secretion rates of adrenaline and noradrenaline increased, the maximum rates being $1.11 \mu \mathrm{g} / \mathrm{kg} / \mathrm{min}$. $(0.64-1.46)$ and $0.47 \mu \mathrm{g} / \mathrm{kg} / \mathrm{min}$. $(0.31-0.73)$, respectively. The relative content of noradrenaline was calculated as $30 \%(24-33)$.

Effect of benzoylcholine on the adrenaline and noradrenaline secretion rates of the adrenal gland

Benzoylcholine in doses of 2 and $4 \mathrm{mg} / \mathrm{kg}$ was injected in four dogs.

Before injection of $2 \mathrm{mg} / \mathrm{kg}$ benzoylcholine the secretion rates of total catecholamines was $0.037 \mu \mathrm{g} / \mathrm{kg} / \mathrm{min}$. $(0.024-0.071)$ and the relative content of noradrenaline was $23 \%(10-33)$ in $\operatorname{dogs} 8,9$, and 10. In $\operatorname{dog} 11$, the noradrenaline content of the adrenal venous blood was unmeasurably small. After injection of $2 \mathrm{mg} / \mathrm{kg}$ benzoylcholine the secretion rate of adrenaline increased to $1.18 \mu \mathrm{g} / \mathrm{kg} /$ 
TABLE III. Effect of Benzoylcholine upon the Secretion Rate of Adrenaline and Noradrenaline of the Adrenal Gland in the Dog

\begin{tabular}{|c|c|c|c|c|c|c|c|}
\hline \multirow{4}{*}{$\begin{array}{l}\text { Animal } \\
\text { No. }\end{array}$} & \multirow{4}{*}{$\begin{array}{l}\text { Body wt. } \\
(\mathrm{kg}) \\
\text { and sex }\end{array}$} & \multirow{4}{*}{$\begin{array}{l}\text { Dose of } \\
\text { benzoyl- } \\
\text { choline } \\
\text { (mg/kg) }\end{array}$} & \multicolumn{3}{|c|}{$\begin{array}{l}\text { Adrenaline and noradrenaline } \\
\text { in adrenal venous blood }\end{array}$} & \multirow{2}{*}{\multicolumn{2}{|c|}{$\begin{array}{c}\text { Secretion rate of adrenaline } \\
\text { and noradrenaline } \\
(\mu \mathrm{g} / \mathrm{kg} / \mathrm{min} .)\end{array}$}} \\
\hline & & & \multirow{2}{*}{\multicolumn{2}{|c|}{$\begin{array}{c}\text { Concentration } \\
(\mu \mathrm{g} / \mathrm{cc})\end{array}$}} & \multirow{3}{*}{$\begin{array}{l}\text { Per cent } \\
\text { noradre- } \\
\text { naline }\end{array}$} & & \\
\hline & & & & & & Adr. & Noradr. \\
\hline & & & Adr. & Noradr. & & & \\
\hline 8 & $\begin{array}{c}8.3 \\
3\end{array}$ & 4 & $\begin{array}{c}(0.28) \\
(0.10) \\
4.60 \\
(0.07) \\
(0.06) \\
6.23\end{array}$ & $\begin{array}{c}(0.03) \\
(0.05) \\
0.10 \\
(0.02) \\
(0.01) \\
0.03\end{array}$ & $\begin{array}{c}(10) \\
(33) \\
2 \\
(22) \\
(14) \\
0.5\end{array}$ & $\begin{array}{c}(0.064) \\
(0.028) \\
1.98 \\
(0.021) \\
(0.018) \\
3.43\end{array}$ & $\begin{array}{c}(0.007) \\
(0.014) \\
0.043 \\
(0.006) \\
(0.003) \\
0.017\end{array}$ \\
\hline 9 & $\underset{f}{10 .} 2$ & 4 & $\begin{array}{c}(0.12) \\
(0.10) \\
3.39 \\
(0.15) \\
(0.18) \\
5.61\end{array}$ & $\begin{array}{c}(0.04) \\
(0.03) \\
0.74 \\
(0.05) \\
(0.03) \\
0.90\end{array}$ & $\begin{array}{c}(25) \\
(25) \\
18 \\
(25) \\
(14) \\
14\end{array}$ & $\begin{array}{c}(0.024) \\
(0.023) \\
1.32 \\
(0.024) \\
(0.032) \\
1.74\end{array}$ & $\begin{array}{c}(0.008) \\
(0.007) \\
0.29 \\
(0.008) \\
(0.005) \\
0.28\end{array}$ \\
\hline 10 & $\begin{array}{c}8.2 \\
j\end{array}$ & 4 & $\begin{array}{c}(0.07) \\
(0.06) \\
2.16 \\
(0.17) \\
(0.13) \\
2.72 \\
\end{array}$ & $\begin{array}{c}(0.02) \\
(0.02) \\
0.13 \\
(0.03) \\
(0.05) \\
0.64\end{array}$ & $\begin{array}{c}(22) \\
(25) \\
6 \\
(15) \\
(28) \\
19\end{array}$ & $\begin{array}{c}(0.018) \\
(0.018) \\
0.95 \\
(0.031) \\
(0.031) \\
1.85\end{array}$ & $\begin{array}{c}(0.006) \\
(0.006) \\
0.057 \\
(0.008) \\
(0.012) \\
0.44\end{array}$ \\
\hline 11 & $\begin{array}{c}7.5 \\
\delta\end{array}$ & 4 & $\begin{array}{c}(0.03) \\
(0.02) \\
1.01 \\
(0.02) \\
(0.04) \\
2.46\end{array}$ & $\begin{array}{r}(*) \\
(*) \\
0.24 \\
(*) \\
(*) \\
0.21\end{array}$ & 19 & $\begin{array}{c}(0.01) \\
(0.01) \\
0.46 \\
(0.006) \\
(0.01) \\
1.11\end{array}$ & 0.095 \\
\hline
\end{tabular}

The values in parentheses represent the pre-injection ones.

* Immeasurably small amount of noradrenaline.

min. (0.46-1.98), while that of noradrenaline increased to $0.13 \mu \mathrm{g} / \mathrm{kg} / \mathrm{min}$. (0.043-0.29) with the noradrenaline percentage of $11 \%(2-19)$.

Before injection of $4 \mathrm{mg} / \mathrm{kg}$ benzoylcholine the total catecholamine secretion rate was $0.033 \mu \mathrm{g} / \mathrm{kg} / \mathrm{min}$. $(0.021-0.043)$ in dogs 8,9 , and 10. The relative noradrenaline content was $20 \%(14-28)$ of the total catecholamines. In $\operatorname{dog} 11$, however, the amount of noradrenaline in the adrenal venous blood was unmeasurably small. After injection of $4 \mathrm{mg} / \mathrm{kg}$ benzoylcholine the adrenaline secretion rate increased to $2.03 \mu \mathrm{g} / \mathrm{kg} / \mathrm{min}$. (1.11-3.43). The noradrenaline secretion rate increased to $0.21 \mu \mathrm{g} / \mathrm{kg} / \mathrm{min}$. $(0.017-0.44)$. The relative noradrenaline content was $10 \%(0.5-19)$. 


\section{DISCUSSION}

In experiments on dogs, Yamashita, Yuge and Araki ${ }^{2}$ showed that carbaminoylcholine, when injected intravenously, was in the adrenaline-secretory action many times as strong as acetylcholine. This was confirmed by the present study. The effect of $0.5 \mathrm{mg} / \mathrm{kg}$ carbaminoylcholine on the adrenal medullary secretion was found to be almost the same as that of $2 \mathrm{mg} / \mathrm{kg}$ acetylcholine. In addition, it was found in the present study that $2 \mathrm{mg} / \mathrm{kg}$ benzoylcholine induced an increase in adrenaline and noradrenaline secretion from the adrenal gland in almost the same rate as that produced by $2 \mathrm{mg} / \mathrm{kg}$ acetylcholine.

On the contrary, Butterworth and Mann ${ }^{6}$ ) concluded from their results of experiments in cats that benzoylcholine and acetylcholine were more effective than carbaminoylcholine in inducing an increase in adrenal medullary secretion. They evaluated the effects of choline esters on the adrenal medullary secretion by the depletion of adrenal adrenaline and noradrenaline.

After injection of acetylcholine, carbaminoylcholine and benzoylcholine, the secretion rate of the adrenal medullary hormone increased and reached the maximum during the first 30 -second period after the start of injection. The relative proportions of noradrenaline to total catecholamines liberated during the maximum secretion rate period were calculated as $14 \pm 3.3 \%$ (mean \pm standard error), $31 \pm 2.7 \%$, and $11 \pm 2.6 \%$, respectively. Thus the relative proportion of noradrenaline to total catecholamines liberated after injection of carbaminoylcholine was significantly larger than that after injection of acetylcholine $(\mathrm{P}<.01)$ and of benzoylcholine $(\mathrm{P}<.001)$. On the other hand, the ratio of noradrenaline to total catecholamines after acetylcholine and benzolycholine was almost the same $(\mathrm{P}>0.6)$.

In experiments of Butterworth and $\mathrm{Mann}^{6 /}$ on cats, the liberation of similar proportions of adrenaline and noradrenaline was induced by injections of acetylcholine, carbaminoylcholine and benzoylcholine. In this respect no definite difference was found between effects of carbaminoylcholine and acetylcholine (or benzoylcholine).

These discrepancies between the results of the present study and those of Butterworth and Mann might be due to the difference of animal species and/or of methods of evaluation of adrenal catecholamine secretion rate.

De Schaepdryver ${ }^{10}$ estimated the adrenaline and noradrenaline secretion rate in dogs anesthetized with morphine and chloralosane. After injection of $1 \mathrm{mg} / \mathrm{kg}$ and $2 \mathrm{mg} / \mathrm{kg}$ acetylcholine the relative noradrenaline content was measured as $24 \%$ and $19 \%$ of the total catecholamines, respectively. His estimates are somewhat higher than those of the present study. 


\section{SUMMARY}

In dogs anesthetized with sodium pentobarbital, the adrenal venous blood was collected by the lumbar route method. Differential estimation of adrenaline and noradrenaline contents of the whole blood samples was made by a modification of the Weil-Malherbe and Bone method. After atropinization, an intravenous injection of acetylcholine, carbaminoylcholine, or benzoylcholine was made.

By the injection of choline esters the adrenal adrenaline and noradrenaline secretion rates were increased markedly. The relative amount of noradrenaline to the total catecholamines liberated after injection of carbaminoylcholine was on the average $31 \%$ and that after acetylcholine and benzoylcholine was $14 \%$ and $11 \%$, respectively.

The author is grateful to Dr. K. Hirai who provided valuable assistance in the present study and to Prof. T. Suzuki for criticizing the manuseript.

\section{References}

1) Feldberg, W., Arch. exper. Path. u. Pharmakol., 1932, 168, 287.

2) Yamashita, K., Yuge, D. \& Araki, M., Kumamoto Med. J., 1957, 10, 12.

3) Suzuki, T., Tanaka, I. \& Yamashita, K., Tohoku J. Exper. Med., 1958, 68, 133.

4) Zinnouchi, S., ibid., 1959, 70, 341.

5) Yamashita, K. \& Zinnocuhi, S., Acta med. nagasaki., 1960, 5, 127.

6) Butterworth, K.R. \& Mann, M., J. Pharm. Pharmacol., 1958, 10, 295.

7) Akimoto, H., To be published in Kumamoto Med. J.

8) Weil-Malherbe, H. \& Bone, A.D., Lancet, 1953, 264, 974.

9) Satake, Y., Sugawara, T. \& Watanabe, M., Tohoku J. Exper. Med., 1927, 8, 501.

10) De Schaepdryver, A.F., Arch. internat. Pharmacodyn., 1959, 121, 222. 